\title{
Experimental study on the influencing factors of SBBR nitrosation controlled by sodium chlorate inhibitor
}

\author{
Yafeng $\mathrm{Li}^{1}$, Chong $\mathrm{Gao}^{1, *}$ and Jianbo $\mathrm{Wu}^{1}$ \\ ${ }^{1}$ Municipal and environmental engineering, Shenyang Jianzhu University, Shenyang, Liaoning, 110000, China
}

\begin{abstract}
The research takes low $\mathrm{C} / \mathrm{N}$ ratio sewage as the research object, and quickly realizes the accumulation of nitrite nitrogen by adding inhibitors into the SBBR reactor, and realizes the nitrogen removal by anaerobic ammonia oxidation in the reactor. Determining the optimal operating parameters is of farreaching significance for the treatment of wastewater with high ammonia nitrogen and low $\mathrm{C} / \mathrm{N}$ and achieving economical and efficient nitrogen removal. Control the ammonia oxidation reaction, keep the nitrification process in the nitrosation stage, and realize the rapid accumulation of $\mathrm{NO}_{2}^{-}-\mathrm{N}$ is the problem that the reactor needs to solve. This experiment uses a combination of batch test and periodic test to conduct experimental research on various influencing factors in the partial nitrosation process: temperature, $\mathrm{pH}, \mathrm{DO}$ and find the best operating conditions to achieve high-efficiency accumulation of $\mathrm{NO}_{2}^{-}-\mathrm{N}$ and optimize the reaction conditions.
\end{abstract}

\section{Introduction}

SBBR (Sequencing batch biofilm reactor) is a biological denitrification process developed on the basis of the SBR process. The activated sludge method and the biofilm method are organically combined with different fillers in the reactor as the growth environment for microorganisms. A method of combining ${ }^{[1]}$. The filler has a certain effect on the treatment effect of the SBBR reactor, and PU sponge is used as a filler ${ }^{[2]}$. This research takes SBBR process as the main body and polyurethane sponge as the filler. The experiment is equipped with R1 and R2 reactors. $\mathrm{R} 1$ uses sodium chlorate inhibitor for culture and R2 uses traditional culture methods to domesticate the sludge which is contrasted with R1. Through experimental research on various influencing factors in the nitrosation process: temperature, $\mathrm{pH}$ and $\mathrm{DO}$, the optimal reaction conditions are found to provide theoretical support for optimizing the reaction device. The experimental setup is shown in Figure 1.



Fig1.. Schematic diagram of SBBR reaction device

\section{The influence of temperature on nitrosation reaction}

The environmental factors at this stage are controlled as follows: control the R1 inlet water $\mathrm{NH}_{4}{ }^{+}-\mathrm{N}$ to $150 \mathrm{mg} \cdot \mathrm{L}^{-1}$, add $\mathrm{NaClO}_{3}$ to a concentration of $1.0 \mathrm{~mol} \cdot \mathrm{L}^{-1}, \mathrm{pH}$ stabilized between 7.5 and 8.0, adjust the gas flowmeter to control the aeration volume It is $300 \sim 400 \mathrm{~mL} \cdot \mathrm{min}^{-1}$ to stabilize the DO concentration at about $0.5 \mathrm{mg} \cdot \mathrm{L}^{-1}$. Set the temperature gradient to $15^{\circ} \mathrm{C}, 20^{\circ} \mathrm{C}, 25^{\circ} \mathrm{C}, 28^{\circ} \mathrm{C}, 30^{\circ} \mathrm{C}$, $32^{\circ} \mathrm{C}$ and $35^{\circ} \mathrm{C}$. The reactor adopts the operation mode of water intake (instantaneous)-aeration (4h)-sedimentation (2h)-drainage (instantaneous)-idle (2h). It runs 3 cycles per day and runs continuously for 7 days. Regularly check the various indicators of the incoming and outgoing water every day to investigate the effect of temperature on the removal of $\mathrm{NH}_{4}{ }^{+}-\mathrm{N}$ and the effect of $\mathrm{NO}_{2}{ }^{-}-\mathrm{N}$ accumulation. The test results are shown in Figure 2 and Figure 3.

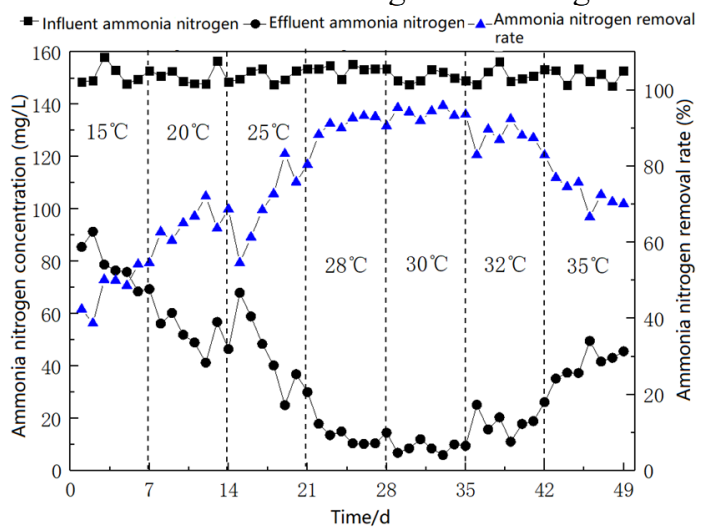

Fig2. The effect of temperature on the removal effect of $\mathrm{NH}_{4}{ }^{+}$$\mathrm{N}$ 




Fig3. The influence of temperature on $\mathrm{NO}_{2}-\mathrm{N}$ accumulation effect

It can be seen from Figure 2 that when the control temperature is between $28^{\circ} \mathrm{C}$ and $32^{\circ} \mathrm{C}$, the $\mathrm{NH}_{4}{ }^{+}-\mathrm{N}$ removal rate in the reactor is very high, and the average removal rate of $\mathrm{NH}_{4}{ }^{+}-\mathrm{N}$ is $90.86 \%$; The effluent $\mathrm{NH}_{4}{ }^{+}-\mathrm{N}$ concentration is also relatively stable, and the average effluent $\mathrm{NH}_{4}{ }^{+}-\mathrm{N}$ concentration is $13.76 \mathrm{mg} \cdot \mathrm{L}^{-1}$. Both the highest $\mathrm{NH}_{4}{ }^{+}-\mathrm{N}$ removal rate and the lowest effluent $\mathrm{NH}_{4}{ }^{+}-\mathrm{N}$ concentration are within this range (both at $30^{\circ} \mathrm{C}$ ), and the nitrifying bacteria are extremely active and have the best metabolism. When the temperature is low $\left(20^{\circ} \mathrm{C}\right)$ or high $\left(35^{\circ} \mathrm{C}\right)$, the $\mathrm{NH}_{4}{ }^{+}-\mathrm{N}$ removal effect is average, and the curve drops when the temperature is high. When the temperature is $25^{\circ} \mathrm{C}$, the removal rate of $\mathrm{NH}_{4}{ }^{+}-\mathrm{N}$ is low, only $54.61 \%$. After timely repair, the removal rate of $\mathrm{NH}_{4}{ }^{+}-\mathrm{N}$ is significantly improved, and the water output effect is optimized again.

Analyzing Figure 3 found that when the reactor is at $15^{\circ} \mathrm{C}$ and $20^{\circ} \mathrm{C}$, the accumulation effect of $\mathrm{NO}_{2}^{-}-\mathrm{N}$ is general. With the further increase of the temperature in the reactor, the $\mathrm{NO}_{2}^{-}-\mathrm{N}$ concentration in the effluent rose significantly during the $7 \mathrm{~d}$ test time at $25^{\circ} \mathrm{C}$, from the initial $38.2 \mathrm{mg} \cdot \mathrm{L}^{-1}$ to $89.6 \mathrm{mg} \cdot \mathrm{L}^{-1}$, the average accumulation rate of $\mathrm{NO}_{2}^{-}-\mathrm{N}$ reaches $66.65 \%$; at $28^{\circ} \mathrm{C}$, the effluent quality is optimized, the $\mathrm{NO}_{3}{ }^{-}-\mathrm{N}$ concentration of effluent is lower than $20 \mathrm{mg} \cdot \mathrm{L}^{-1}, \mathrm{NO}_{2}^{-}-\mathrm{N}$ accumulation is stable, and the fluctuation is small; the reaction is further optimized at $30^{\circ} \mathrm{C}$. At this stage, the reactor has the highest $\mathrm{NO}_{2}^{-}-\mathrm{N}$ accumulation rate, which is $94.81 \%$; the average concentration of $\mathrm{NO}_{3}-\mathrm{N}$ in the effluent is only $10.76 \mathrm{mg} \cdot \mathrm{L}^{-1}$. At $32^{\circ} \mathrm{C}$ and $35^{\circ} \mathrm{C}$, although the accumulation of $\mathrm{NO}_{2}^{-}-\mathrm{N}$ is still considerable, the concentration of $\mathrm{NO}_{2}^{-}-\mathrm{N}$ and $\mathrm{NO}_{3}^{-}-\mathrm{N}$ in the effluent changes greatly, and the water quality is relatively poor, which is not conducive to the stable operation of the nitrosation reaction.

The test results show that temperature is an important factor affecting the nitrosation reaction. When the microorganisms are at different temperatures, the removal rate of $\mathrm{NH}_{4}{ }^{+}-\mathrm{N}$ and the accumulation rate of $\mathrm{NO}_{2}^{-}-\mathrm{N}$ have obvious differences. When the temperature is controlled at about $28 \sim 30^{\circ} \mathrm{C}$, the effluent quality is in line with expectations. When the temperature is low, the effluent quality is poor, the effluent $\mathrm{NO}_{2}^{-}-\mathrm{N}$ and $\mathrm{NO}_{3}^{-}-\mathrm{N}$ concentrations are similar, and the effluent $\mathrm{NH}_{4}{ }^{+}-\mathrm{N}$ concentration is higher. When the temperature is high, the removal rate of $\mathrm{NH}_{4}{ }^{+}-\mathrm{N}$ and the accumulation rate of $\mathrm{NO}_{2}{ }^{-}$ -N both decrease to varying degrees. In summary, the optimum temperature range for the nitrosation process is $28 \sim 30^{\circ} \mathrm{C}$, and the best temperature is around $30^{\circ} \mathrm{C}$. This is similar to the results of $\mathrm{Yoo}^{[3]}$.

\section{The influence of $\mathrm{pH}$ on nitrosation reaction}

The specific operation method of the test is as follows: control the temperature at $(28 \pm 1){ }^{\circ} \mathrm{C}$, maintain the DO concentration between 0.5 and $1.0 \mathrm{mg} / \mathrm{L}$, the influent $\mathrm{NH}_{4}{ }^{+}-\mathrm{N}$ concentration at about $150 \mathrm{mg} \cdot \mathrm{L}^{-1}$, run 2 cycles per day, single The cycle process is water intake (instantaneous)-aeration (6h)-sedimentation (3h)-drainage (instantaneous)-idle (3h). The test uses $10 \%$ dilute hydrochloric acid and sodium bicarbonate solution to adjust the $\mathrm{pH}$ value, and conducts 3 batches of tests. Each batch is for 2 sets of parallel tests, and the $\mathrm{pH}$ is controlled between 6.0, 6.5, 7.0, 7.5, 8.0, and 8.5. Each batch was run for 7 days, and various water inlet and outlet indicators were checked regularly to investigate the influence of $\mathrm{pH}$ on the removal effect of $\mathrm{NH}_{4}{ }^{+}-\mathrm{N}$ and the effect of $\mathrm{NO}_{2}^{-}-\mathrm{N}$ accumulation. The test results are shown in Figure 4 and Figure 5.



Fig4. The effect of $\mathrm{pH}$ on the removal of $\mathrm{NH}_{4}{ }^{+}-\mathrm{N}$

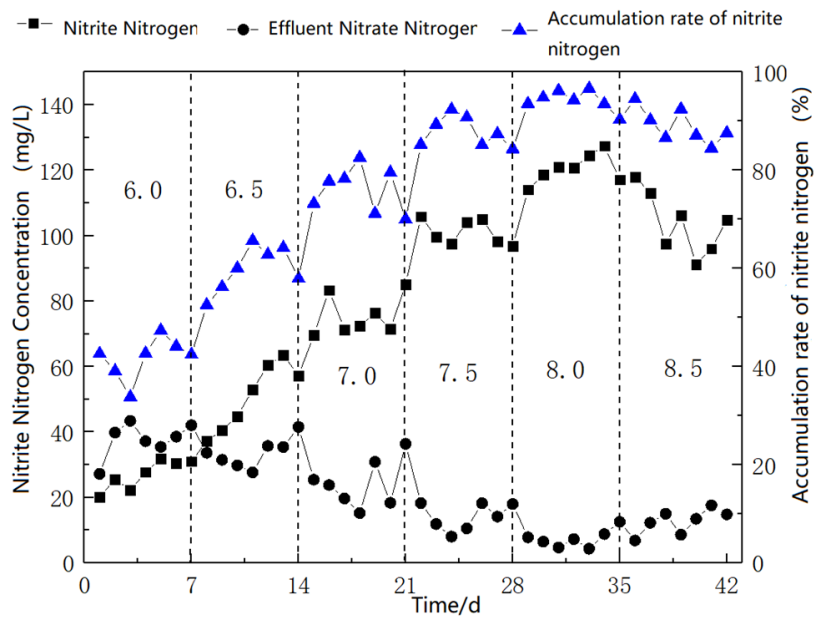

Fig5. The effect of $\mathrm{pH}$ on the accumulation of $\mathrm{NO}_{2}-\mathrm{N}$ 
It can be seen from Figure 4 that when the microorganisms are in an alkaline environment, the $\mathrm{NH}_{4}{ }^{+}-$ $\mathrm{N}$ removal effect is better, with an average removal rate of $87.86 \%$, which is $20 \%$ higher than that of acidic conditions. When the $\mathrm{pH}$ is 6.0 , the average concentration of $\mathrm{NH}_{4}^{+}-\mathrm{N}$ in the effluent is $73.95 \mathrm{mg} \cdot \mathrm{L}^{-1}$. Observing the No. 2 reactor, when the $\mathrm{pH}$ is 6.5 , the removal effect of $\mathrm{NH}_{4}{ }^{+}-\mathrm{N}$ is average. Analyzing the data of the second set of parallel experiments $(\mathrm{pH}=7.0, \mathrm{pH}=7.5)$, it was found that the microbial activity was higher at this stage, the effluent quality was better, and the removal of $\mathrm{NH}_{4}{ }^{+}-\mathrm{N}$ was stable at $\mathrm{pH} 7.5$, and the average removal rate was high. When the $\mathrm{pH}$ value is 8.0 , the average removal rate of $\mathrm{NH}_{4}^{+}-\mathrm{N}$ at this stage is the highest, $91.44 \%$, indicating that the microbial activity is the best at this stage, and the removal rate of No. 2 reactor during the same period is also considerable.

As shown in Figure 5, as the $\mathrm{pH}$ increases, the $\mathrm{NO}_{2}^{-}-\mathrm{N}$ concentration in the effluent rises simultaneously, and the $\mathrm{NO}_{2}^{-}-\mathrm{N}$ accumulation effect becomes better and better. Under acidic conditions, the effluent $\mathrm{NO}_{2}^{-}-\mathrm{N}$ concentration is not much different from the effluent $\mathrm{NO}_{3}{ }^{-}$ - $\mathrm{N}$ concentration, and the reactor system behaves as traditional nitric acid nitrification ${ }^{[4]}$. When the $\mathrm{pH}$ value increases to 7.0 and 7.5 , the effluent water quality is optimized, and the average concentration of $\mathrm{NO}_{2}{ }^{-}-\mathrm{N}$ in the effluent is $75.69 \mathrm{mg} \cdot \mathrm{L}^{-1}$ and $101.04 \mathrm{mg} \cdot \mathrm{L}^{-1}$. The system has a higher accumulation rate of $\mathrm{NO}_{2}^{-}-\mathrm{N}$; When the $\mathrm{pH}$ in the reactor reaches 8.5 , the accumulation rate of $\mathrm{NO}_{2}^{-}-\mathrm{N}$ remains at a high level, with an average accumulation rate of $88.01 \%$.

The test results show that the $\mathrm{pH}$ value has an important influence on the nitrosation reaction, and controlling the $\mathrm{pH}$ between 7.5 and 8.0 in an alkaline environment is conducive to the realization of the nitrosation reaction ${ }^{[5]}$.

\section{The influence of DO on nitrosation reaction}

Nitrifying bacteria belong to the aerobic flora. Studies have found that the oxygen half-saturation constant of NOB is greater than that of AOB.The concentration of DO is vital to promote the renewal of biofilms and the formation of sludge granulation Role ${ }^{[6]}$.

The specific operation method of the test is as follows: control the R1 inlet water $\mathrm{NH}_{4}^{+}-\mathrm{N}$ concentration to about $150 \mathrm{mg} \cdot \mathrm{L}^{-1}, \mathrm{pH}$ between 7.5 and 8.0 , and the specified temperature range at about $28^{\circ} \mathrm{C}$. The operating state of the SBBR reactor is: water inlet (instantaneous) -Aeration (6h)-Sedimentation (3h)-Drainage (instantaneous)-Idle (3h), run 2 complete cycles a day, control the DO concentration in the reactor to be $0.5 \mathrm{mg} / \mathrm{L}, 1 \mathrm{mg} / \mathrm{L}$, $1.5 \mathrm{mg} / \mathrm{L}$ respectively , $2 \mathrm{mg} / \mathrm{L}, 2.5 \mathrm{mg} / \mathrm{L}$, each group of DO concentration runs stably for 7 days, and each water inlet and outlet indicators are checked regularly every day to investigate the nitrosation situation under different DO concentrations. See attached table 6 for test data. Test results are shown in Figure 6 and Figure 7.



Fig6. The effect of DO on the removal effect of $\mathrm{NH}_{4}{ }^{+}-\mathrm{N}$

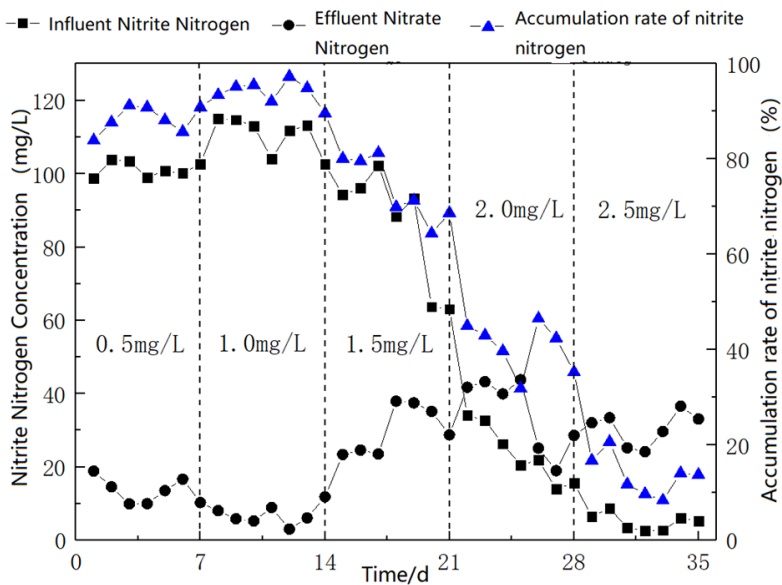

Fig7. The influence of DO on the cumulative effect of $\mathrm{NO}_{2}{ }^{-}-\mathrm{N}$

It can be seen from Figure 6 that when the concentration of DO increases, the removal effect of $\mathrm{NH}_{4}{ }^{+}-\mathrm{N}$ in the reactor is not significantly affected. Under these 5 different gradient concentrations, the average removal rates of $\mathrm{NH}_{4}{ }^{+}-\mathrm{N}$ are $88.48 \%$ and $91.60 \%$ respectively, $84.21 \%, 94.66 \%$ and $92.27 \%$, have always maintained a high level. Every time the DO concentration increases, the effluent $\mathrm{NH}_{4}{ }^{+}-\mathrm{N}$ concentration changes little. The effluent $\mathrm{NH}_{4}^{+}-\mathrm{N}$ concentration is stable at about $12 \mathrm{mg} \cdot \mathrm{L}^{-1}$ within 35 days, and the effluent quality is good.

As shown in Figure 7, when the DO concentration in the reactor is maintained at $0.5 \mathrm{mg} \cdot \mathrm{L}^{-1}$ and $1.0 \mathrm{mg} \cdot \mathrm{L}^{-1}$, the average concentration of $\mathrm{NO}_{2}^{-}-\mathrm{N}$ in the effluent is $105.95 \mathrm{mg} \cdot \mathrm{L}^{-1}$, increasing the DO concentration to $1.5 \mathrm{mg} \cdot \mathrm{L}^{-1}$, the nitrification in the reactor is weakened. When the DO concentration is controlled to $2.0 \mathrm{mg} \cdot \mathrm{L}^{-1}$, the $\mathrm{NO}_{2}^{-}-\mathrm{N}$ accumulation effect will be further deteriorated, and the $\mathrm{NO}_{2}^{-}-\mathrm{N}$ concentration in the effluent will drop significantly. When $\mathrm{DO}=2.5 \mathrm{mg} \cdot \mathrm{L}^{-1}$, there is almost no accumulation of $\mathrm{NO}_{2}^{-}-\mathrm{N}$ in the reactor, but the concentration of $\mathrm{NO}_{3}{ }^{-}-\mathrm{N}$ in the effluent has not been further increased and maintained at about $30 \mathrm{mg} \cdot \mathrm{L}^{-1}$. The oxygen environment promotes the denitrification reaction, and a large amount of nitrogen is decomposed into $\mathrm{N}_{2}$ and discharged from the reactor.

The test results show that the concentration of DO has a great influence on the nitrification reaction. The system carries out the whole nitrification and denitrification 
reaction in a high dissolved oxygen environment, and nitrogen is more in the form of $\mathrm{N}_{2}$. In a low dissolved oxygen environment, it is conducive to the accumulation of $\mathrm{NO}_{2}^{-}-\mathrm{N}$, so that the oxidation process in the system stays in the nitrosation stage.

However, a too low DO concentration will cause a large number of filamentous bacteria to multiply. Taking into account comprehensively, the nitrosation effect is best when the DO concentration is controlled at $1.0 \mathrm{mg} \cdot \mathrm{L}^{-}$ 1

\section{Conclusion}

The experiment investigated the influence of temperature, $\mathrm{pH}$ and $\mathrm{DO}$ factors on the nitrosation performance of the reactor by studying the SBBR reactor with sodium chlorate inhibitor, and determined the optimal reaction conditions for each factor. The test results showed : Temperature is an important factor affecting the nitrosation reaction. When the temperature range is around $30^{\circ} \mathrm{C}$, the nitrosation process is the best; the $\mathrm{pH}$ value has an important influence on the nitrosation reaction. Controlling the $\mathrm{pH}$ between 7.5 and 8.0 is beneficial to the realization of an alkaline environment. Nitrosation reaction: Among them, DO concentration has the greatest influence on nitrosation reaction. When DO concentration is controlled at $1.0 \mathrm{mg} \cdot \mathrm{L}^{-1}$, nitrosation is the best.

\section{Acknowledgments}

This article is one of the phased results of the National Social Science Fund's general project "China National Critical Project for Science and Technology on Water Pollution Prevention and Control" (2018ZX07601001), and thank you for the help of teachers and students on the paper.

\section{References}

1. De Graaff M S, Temmink H, Zeeman G, et al. Autotrophic nitrogen removal from black water: Calcium addition as a requirement for settle ability $[\mathrm{J}]$. Water Research. 45(1):63-74,(2011).

2. Zhou Xin, Zhang Zeqian, Sun Hailong. Study on the start-up characteristics of PU sponge filler-SBBR treating ammonia nitrogen wastewater[J]. China Water \& Wastewater, 33(17):84-88,(2017).

3. Yoo H. Nitrogen removal from synthetic wastewater by simultaneous nitrification and denitrification via nitrite in an intermittently-aeated reactor[J]. Water Research, 33(1):146-152,(1999).

4. Qian Guanglei, Shao Qiang, Zhang Yanfang. Realization of SBR short-range nitrification process based on DO control[J]. Environmental Engineering Journal, 9(06):2864-2868,(2015).

5. Zhang Min et al. Effect of $\mathrm{C} / \mathrm{N}$ and Sludge Concentration on the $\mathrm{pH}$-Regulated Nitrosation System.[J].Environmental science ,40,(2019).
6. Zhang Nan. Research on the treatment of domestic sewage in a membrane bioreactor under low oxygen conditions [D]. Tongji University,(2006). 